\title{
Entrepreneurial Orientation
}

\section{among Migrants and Small and Medium Enterprises}

\author{
Olufemi Muibi Omisakin ${ }^{1}$, Camille Nakhid ${ }^{2}$, Romie Littrell ${ }^{3} \&$ Jane Verbitsky $^{2}$ \\ ${ }^{1}$ Auckland University of Technology, New Zealand \\ 2 Auckland University of Technology, Faculty of Culture and Society, School of social sciences and Public \\ policy,New Zealand \\ ${ }^{3}$ Auckland University of Technology, Faculty of Law and Business, Department of International Business, New \\ Zealand \\ Correspondence: Olufemi Muibi Omisakin, Auckland University of Technology, New Zealand
}

Received: January 13, 2016

Accepted: February 1, $2016 \quad$ Online Published: February 10, 2016

doi:10.5430/jbar.v5n1p7

URL: http://dx.doi.org/10.5430/jbar.v5n1p7

\begin{abstract}
Entrepreneurship is a process of creating value by bringing together a unique package of resources to exploit entrepreneurship opportunities. The importance of entrepreneurial activities in society has been acknowledged in the entrepreneurship literature. It has been suggested that entrepreneurial strategies, in terms of entrepreneurial orientation (EO), contribute greatly to entrepreneurship performance (Lumpkin \& Dess, 1996; Miller, 1987; Reynolds, 2000). EO is often mentioned as an antecedent of firm growth, competitive advantage, and superior performance. Prior research confirms that a positive relationship exists between EO and firm performance (Wiklund \& Shepherd, 2005; Wang, 2008; Runyan, 2008). The success of enterprises are dependent on EO and a range of other factors including age, gender, culture, education, managerial know-how, length of time, size of enterprise, capital, and network connection.

Three disciplines have provided primary contributions to the theoretical development of entrepreneurial orientation (EO). These are economics, social psychology, and strategic management (Mitchell et al., 2002). EO refers to the strategy-making processes and styles of a firm that engage in entrepreneurial activities. There are two schools of thought on EO: the Unidimensional School with three dimensions (proactiveness, risk-taking, and innovativeness) and the multidimensional school with five dimensions (innovativeness, risk-taking, autonomy, proactiveness, and competitive aggressiveness).

An overview of the entrepreneurial literature shows that there has been little focus on the influence of EO on migrant enterprises. Therefore, the objective of this study will be to examine the relationship between five dimensions of EO and entrepreneurial performance. The study will also assess the moderating influence of environment (environmental characteristics) on the EO-performance relationship.
\end{abstract}

Keywords: Migrants, Migrant enterprises, Migrant entrepreneur, Entrepreneurship, Environment, Business performance

\section{Rationale of the Study}

An overview of the entrepreneurial literature shows that there has been little focus on the influence of entrepreneurial orientation (EO) on migrant enterprises. Therefore, this identified gap will be the focus of this study. The study will use the multidimensional model of EO to evaluate a series of questions pertaining to the influence of $\mathrm{EO}$ on the performance of migrant small and medium businesses as well as environmental effects on the EO-firm performance relationship. Data will be collected via interview questions from 15-20 migrant small business owners.

\section{Introduction}

The theoretical and empirical contributions of the study will provide insight into the influence of EO on entrepreneur success. The findings from the study will add to the understanding of the need for the multi-dimensional construct of EO and its effect on business success, especially that of business start-ups, as well as the influence of environmental factors on a business. The study will also analyse other factors that contribute to small and medium enterprises (SME) success among migrants in New Zealand. 
Entrepreneurship researchers have generally extolled the importance of entrepreneurial activities. It is often assumed that entrepreneurial orientation enhances firm performance. This is noted in the rise of the literature in this area (Indarti \& Langenberg, 2005; Lumpkin \& Dess, 1996; Lumpkin.., Corgliser, \& Schneider, 2009; Miller, 1987; Wiklund... \& Shepherd, 2005). Most entrepreneurship scholars agree that an entrepreneurial strategy has the potential to impact greatly on a firm's performance. Wiklund and Shepherd (2003) maintain that entrepreneurship is a crucial factor in firms being able to obtain a competitive advantage.

Entrepreneurship is a popular construct with various meanings. There is no consensus on the definition of entrepreneurship, hence many researchers adopt their own definitions of entrepreneurship and create their own terms within the area. Generally, entrepreneurship is regarded as the creation of wealth, enterprise, innovation, change, employment, value, and creation of growth among others (Morris, Kuratko, \& Covin, 2008). Morris et al. (2002) concluded that entrepreneurship is the process of creating value by bringing together a unique package of resources to exploit an opportunity.

Entrepreneurial orientation (EO) is an aspect of entrepreneurship that encapsulates its strategies for success. Rauch, Wiklund, Lumpkin, and Frese (2009) conclude that EO represents the policies and practices that provide a basis for entrepreneurial decisions and actions. Lumpkin \& Dess (1996) describe EO as a multi-dimensional process consisting of five dimension. These dimensions are risk taking, competitive aggressiveness, autonomy, proactiveness, and innovativeness. Drawing from the above definitions, it is obvious that firm behaviour is a central and essential element in the entrepreneurial process. In other words, entrepreneurial orientation refers to how firms act in the areas of risk taking, innovativeness, proactiveness, autonomy, and competitive aggressiveness. Entrepreneurship researchers agree that EO is potentially important in the performance measurement of small and medium enterprises (SMEs).

Several research investigations have revealed that entrepreneurial orientation has a significant and positive influence on business performance (Wiklund \& Shepherd, 2003; Wiklund \& Shepherd, 2005; Keh et al., 2007; Wang, 2008; Runyan et al., 2008). Wiklund and Shepherd, $(2003,2005)$ found that EO has a positive influence on firm performance but that the environment has a controlling influence on the EO-firm performance relationship. Wang (2008) and Runyan et al. (2008) posit that EO is important for business performance, likewise EO has both a direct and indirect influence on firm performance (Keh et al., 2007). This suggests that firms that adopt more EO perform better than those that lack such orientation. This is related to the fact that today's dynamic business environment requires a firm to regularly innovate, take risk into account, give room for autonomy, be proactive, and aggressively compete to maintain or find a new position in the market place.

Despite the consensus among many scholars of entrepreneurship that there is a positive relationship between EO and business performance, studies carried out by several other scholars do not point to this direction. Research on the direct effect of each dimension of EO on performance varies. In fact, some findings show that there is no correlation between EO dimensions and performance (Hughes \& Morgan, 2007). Similarly, investigations on the direct effect of EO on firm performance have not provided a comprehensive description of the relationship (Wang, 2008; Wiklund \& Shepherd, 2005). Covin and Slevin (1994) and Slater and Narver (2000) were unable to find relevant evidence of a positive relationship between EO and business performance. Therefore, empirical research findings of an EO-firm performance relationship have been mixed. This is because some of the research in this area ignores factors that may mediate the strength of EO on firm performance. However, for clarity and an in-depth understanding of an EO-performance relationship, this study will take into consideration certain environmental factors that may have a controlling effect on the EO-performance relationship. 
Table 1. Definition of Constructs

\begin{tabular}{|c|c|c|}
\hline Key Terms & Definition & Reference \\
\hline Risk-taking & $\begin{array}{l}\text { Risk-taking involves firms taking calculated business } \\
\text { opportunities when the outcome of the risk cannot be } \\
\text { determined immediately. }\end{array}$ & $\begin{array}{l}\text { (Lumpkin. \& Dess, } \\
\text { 2001) }\end{array}$ \\
\hline $\begin{array}{l}\text { Competitive } \\
\text { aggressiveness }\end{array}$ & $\begin{array}{l}\text { Competitive aggressiveness refers to the way firms react to } \\
\text { trends and demands that exist in their market. }\end{array}$ & $\begin{array}{l}\text { (Lumpkin. \& Dess, } \\
\text { 2001) }\end{array}$ \\
\hline Autonomy & $\begin{array}{l}\text { Autonomy refers to the independent action of individuals or } \\
\text { teams in developing an idea and/or vision and supporting its } \\
\text { development from idea to completion. }\end{array}$ & $\begin{array}{l}\text { (Lumpkin } \quad \& \\
\text { 1996) }\end{array}$ \\
\hline Proactiveness & $\begin{array}{l}\text { Proactiveness connotes firms acting in anticipation of future } \\
\text { problems, needs, and or change. It involves the identification } \\
\text { and evaluation of new opportunities. }\end{array}$ & $\begin{array}{l}\text { (Kropp., Linday, \& } \\
\text { Shoham, 2008) }\end{array}$ \\
\hline Innovativeness & $\begin{array}{l}\text { Innovativeness is described as a firm's ability and attempt } \\
\text { to engage in new ideas or to innovate and create processes } \\
\text { that may result in new products. }\end{array}$ & $\begin{array}{l}\text { (Runyan., Droge, \& } \\
\text { Swinney, 2008) }\end{array}$ \\
\hline $\begin{array}{l}\text { Environmental } \\
\text { munificence }\end{array}$ & $\begin{array}{l}\text { Environmental munificence refers to the availability of } \\
\text { resources and the amount of external opportunities that are } \\
\text { present in an environment. }\end{array}$ & (Zahra., 1993) \\
\hline $\begin{array}{l}\text { Environmental } \\
\text { dynamism }\end{array}$ & $\begin{array}{l}\text { Environmental dynamism is the rate of change and } \\
\text { innovation in an industry as well as the uncertainty or the } \\
\text { predictability of the actions of competitors and customers. }\end{array}$ & $\begin{array}{l}\text { (Miller. } \\
\text { 1983) }\end{array}$ \\
\hline $\begin{array}{l}\text { Environmental } \\
\text { hostility }\end{array}$ & $\begin{array}{l}\text { Environmental hostility is defined as the degree of threat to } \\
\text { the firm posed by the multifacetedness, vigour, and intensity } \\
\text { of the competition and the up and down swings of the firm's } \\
\text { principal industry. }\end{array}$ & $\begin{array}{l}\text { (Miller. \& Friesen, } \\
\text { 1983) }\end{array}$ \\
\hline
\end{tabular}

\section{Literature Review}

\subsection{Concept of Entrepreneurship}

The word 'entrepreneur' is French and is literally translated as 'between-taker' 'go-between' (Hisrich \& Peters, 2002a). Cantillon (1734) introduced the term 'entrepreneur' into economic literature and interpreted it as a risk taker. Entrepreneurs are regarded as extraordinary people with a great ability to bring about extraordinary events. Entrepreneurs are therefore regarded as active figures in the business terrain and processes.

Generally, an entrepreneur is seen as the person who bears risk and possesses psychological capacity to energise and coordinate entrepreneurial activities. There are a number of entrepreneurial characteristics and traits that affect business. These include innovation, risk taking, autonomy, perseverance, independence, and internal locus of control (Aggarwal \& Gupta, 2006; Hisrich \& Peters, 2002b; Morris, 2002). However, some scholars have reacted against the approach that only individual qualities and abilities makes an entrepreneur. For instance, Lumpkin and Dess (1996) argue that other factors beyond the entrepreneur's control and ability can also predict entrepreneurial success. The authors view entrepreneurship as the interaction between the individual and opportunities in the environment. It can be concluded that, entrepreneurship involves identification and exploitation of opportunities previously unidentified and unexploited. From the above, entrepreneurship involves multiple events such as recognition of an opportunity and acting on the identified opportunity.

Though the term entrepreneurship has been used for decades, still there is no consensus about its definition and the processes involved (Williams., Round, \& Rodgers, 2010). Morris, Kuratko, and Covin (2008) summarised the common themes found in the entrepreneurship literature as the creation of wealth, enterprise, innovation, change, employment, value, and growth. However, Morris et al. described entrepreneurship as a process of creating value by bringing together a unique package of resources to exploit an opportunity.

Research studies have suggested several factors that affect entrepreneurial success. They include culture, age, education, gender, managerial know-how, industry experience, social skills, entrepreneurial readiness, length of time, 
size of enterprise, and capital (Charney \& Libercap, 2000; Kolveried, 1996; Kristiansen, Furuholt, \& Wahid, 2003; Mazzarol, Volery, Doss, \& Thein, 1999).

It has also been argued that national culture influences entrepreneurial activities, which in turn affect firms' performance. This opinion has been corroborated by other researchers in this area (Lee \& Peterson, 2000; Mueller \& Thomas, 2001). Others have suggested that those aged between 25 and 44 years are the most entrepreneurially active (Kristiansen et al., 2003) and that gender, especially male, helps entrepreneurial intention (Charney \& Libercap, 2000; Kolveried, 1996; Mazzarol et al., 1999) suggest that education produces self-sufficient entrepreneurs.

Other factors shown to influence business success are family background and personal traits and characteristics (Glancey, Greig, \& Pettigrew, 1998). Entrepreneurial readiness, a reference to entrepreneur self-efficacy to succeed and attain business goals, affects business success (Cromie, 2000) and is a foundation to human motivation and personal accomplishment. Kristiansen and Indarti (2004) found a significant correlation between self-efficacy and entrepreneurial intention. In this study, entrepreneurial activities (decision-making styles, practices, processes, and behaviours) of firms will be referred to as entrepreneurial orientation.

\subsection{Entrepreneurial Orientation}

Three disciplines have provided primary contributions to the theoretical development of entrepreneurial orientation (EO). These are economics, social psychology, and strategic management (Mitchell et al., 2002).

- The economic approach of EO is focused on the creation of new venture (Schumpeter, 1934); (Gartner, 1985). Through this, the profitability and growth of an organisation are examined to determine the organisation's entrepreneurial and performance level. With this approach, researchers are able to know the factors that contribute to the entrepreneurial success of an organisation (Levesque \& Shepherd, 2004) .

- The social psychology approach is focused on the individual traits of the entrepreneur rather than the organisation. This involves the risk-taking propensity and competitive aggressiveness of the entrepreneur. This approach has been used to examine traits such as risk-taking propensity and competitive aggressiveness of the entrepreneur in relation to other entrepreneurship traits (Monaughan, 2000).

- The third approach was developed from the strategic management field. This considers the role of the entrepreneur in dictating the strategic organisational objectives and how his/her decision affects the organisation (Mitchell et al., 2002).

These approaches have provided an understanding of entrepreneurial behaviour in an organisation, especially, behaviours and traits relating to a firm's innovativeness, proactiveness and risk-taking, and entrepreneurial orientation contribution to the entrepreneurial nature.

(Lumpkin \& Dess, 1996) refer to entrepreneurial orientation (EO) as management's strategy in relation to risk-taking, self-directed activities, innovativeness, proactiveness, and competitive aggressiveness. Wiklund and Shepherd (2003) describe $\mathrm{EO}$ as policies and practices that provide the basis for entrepreneurial decisions and actions. However, a good number of entrepreneurship scholars have associated EO with a firm's success. Zahra (1995) and Wiklund and Shapherd (2005) suggest that entrepreneurial orientation constitutes a key ingredient for enterprise success and has been found to lead to higher performance. Similarly, Lumpkin and Dess (1996) argue that entrepreneurial orientation is a source of competitive advantage. However, Mintzberg (1973) and Rauch. et al. (2009) contend that for a firm to be entrepreneurial, such a firm needs to take more risks than other firms and be more proactive in searching for new opportunities.

There are two schools of thought on entrepreneurial orientation. The schools of thought differ in their conceptualisation of EO.

The first school of thought proposes three dimensions of EO (Miller 1983). These are innovation, risk-taking, and proactiveness. These dimensions are considered unidimensional constructs, and for a firm to be considered entrepreneurial, these three variables must be present.

The second school of thought queries the rationale for the unidimensionality of EO (Lumpkin \& Dess 1996). Lumpkin and Dess (1996) therefore conceptualised EO as a multi-dimensional construct consisting of five theoretical dimensions (autonomy, innovativeness, risk-taking, proactiveness, and competitive aggressiveness). The authors note that each variable/construct has a unique relationship with performance. However, both dimensions of EO constructs (unidimensional and multidimensional) are widely embraced in the literature. These dimensions are discussed briefly below. 


\subsubsection{Risk-taking}

Risk-taking has always been the principal feature of an entrepreneur (Cantillon, 1734) and part of early entrepreneurship literature. The principal element that separates entrepreneurs from employees is the risk and uncertainty associated with self-employment (Cantillon 1934). While Lumpkin and Dess (2001) argue that risk-taking involves firms taking calculated business opportunities when the outcome of the risk cannot be determined immediately. Similarly Wiklund and Shepherd (2003) suggest that risk-taking orientation is the willingness of an entrepreneurial firm to invest resources in a venture or project where the outcome may be highly uncertain or unknown. Lumpkin and Dess (1996) submit that firms invest substantial funds in ventures with the intent of utilising environmental opportunities and realising higher returns. A non-entrepreneurial firm innovates very little, is highly risk averse, and imitate competitors (Miller, 1983). Positive risk-taking often leads to entrepreneurial success. This explains why firms with risk-taking orientation seize market opportunities, obtain higher returns on investment, and make lucrative marketing deals (Lumpkin \& Dess, 2001). Entrepreneurship scholars submit that firms with a higher risk-taking performance relationship are often attracted to investing in viable ventures with the sole aim of improving performance (Avlonitis. \& Salavou, 2007; Lumpkin \& Dess, 1996; Miller. \& Friesen, 1983). A good entrepreneur is more than self-employed, he/she must be calculative and possess risk-taking behaviour in all aspects of business. Miller, (1983) and Lumpkin and Dess (1996) suggest that the content of risk-taking includes opportunity capitalisation, resource commitment, calculative expectation on returns and uncertainty. Baird and Thomas (1985) propose three types of risk-taking for an entrepreneurial organisation: The first is the risk associated with obtaining a heavy loan to fund a project. When firms borrow heavily, it places intense financial pressure on the firm and erodes their profitability and performance. Sometimes borrowing heavily and an inability to repay may lead to dilution of the entrepreneur's equity in the venture, managerial changes made by the lending party, and change in structure or downsizing of employees or other associated preferred solutions. However, this type of risk is commonly associated with big businesses and/or corporate institutions. The second type of risk-taking is the risk associated with excessive commitment of resources into a particular project or investment. Both small-business and corporate entrepreneurship are involved in this type of risk. It is possible for a firm to start with little funds for a particular project and as it continues, more funds continue to be committed if the expected result has not been attained. Risk is enhanced at the level of continuous resource commitment. The third classification by the authors is the risk of venturing into the unknown. This is common among firms who commit resources to research aimed at a positive result; if the result is negative, the amount invested goes down the drain, leading to a loss. Development of new products, prospecting for crude oil, and technological/operational processes are typical of this type of risk-taking, especially when market size is not considered before embarking on the change.

\subsubsection{Competitive Aggressiveness}

Competitive aggressiveness is the intensity of a firm's efforts to outperform industry rivals (Lumpkin \& Dess, 1996). It involves taking an offensive stance at overcoming threatening competitors in order to control larger market shares. Sometimes it involves head-to-head confrontations or willingly being unconventional from traditional forms of competition. An aggressive firm stepping in and taking over markets might result in product price cuts (Lyon, Lumpkin, \& Dess, 2000) and securing easy access to rival based markets (Rauch, Wiklund, and Frese, 2009). The aggressive marketing of product/services and the improvement of product/service qualities are often embarked upon to stifle competitors out of the market.

The survival and success of new entrants in the industry depend on a firm's aggressive behavioural stance and intense competition (McMillan, 1982). There are three possible ways for firms to aggressively compete. Firms can compete by doing it differently, redefining the product and or market, and outspending the industry leader with the aim of becoming the industry leader (Portter \& Miller, 1985). Firms with competitive aggressive orientation often possess the capabilities to revise the rules of competition, redefine industry boundaries through entry advantage, and improve market position. These actions enable such firms to acquire a substantial share of the market, outperform competitors, and increase earnings.

\subsubsection{Autonomy}

Lumpkin and Dess (1996) consider autonomy as a major construct of EO. It is described as the ability to make decisions and proceed with an action independently without restrictions from the organisation. Autonomy reflects the strong desire of a person to have freedom in the development of an idea and its implementation within an organisation (Lumpkin.. et al., 2009). Autonomy is considered a major trait in EO by Lumpkin and Dess (1996), hence the authors state, "Entrepreneurship has flourished because independently minded people elected to leave secure positions in order to promote novel ideas or venture into new markets, rather than allow organisational 
superiors and processes to inhibit them" (p. 140). From the above, autonomy connotes the will and ability to be self-directed in the pursuit of environmental opportunities and the associated challenges. This enhances a firm's ability to make quick and self-reliant decisions to provide the market with new products and services.

When a firm offers autonomy to its staff, it motivates its staff in a positive manner which may lead to higher firm performance. Firms cannot function entrepreneurially without giving autonomy to the staff (Coulthard, 2007). Employees in an entrepreneurial firm need greater autonomy and self-regulation to determine what actions are required, and when and how to execute them. Socialisation among employees helps build interaction to freely exchange personal and professional knowledge. It enhances internalisation activities. Employees learn through autonomous operations that enrich their experiences and knowledge base in the organisation. This translates to quicker decision making that enhances positive performance.

Two types of autonomy have been identified in the entrepreneurship literature: the autocratic mode and the generic mode. The autocratic mode refers to an entrepreneurial decision-making strategy that allows a strong leader to take decisive risky actions for an enterprise. This type of autonomy is often found in smaller enterprises and owners or managers of firms. The control, vision, and management of the enterprise are anchored on the personality of the owner/manager. Lumpkin and Dess (1996) and Miller (1983) submit that most firms with an autonomous orientation maintain a higher level of entrepreneurial activities which give them an edge over their competitors. The generic mode refers to the decentralisation of expected actions among staff members of a firm. Ideas generated by members of staff are passed through to management for consideration. This is most common in big firms where authority and responsibilities are decentralised and employees are allowed to make contributions in the decision-making process irrespective of status.

\subsubsection{Proactiveness}

Proactiveness refers to the process that anticipates and acts on future needs by "seeking new opportunities which may or may not be related to the present lines of operations, introduction of new products, and brands ahead of competition, strategically eliminating operations which are in the mature or declining stages of life cycle" (Venkatraman, 1989, p. 949). Proactiveness involves the identification and evaluation of new opportunities and the monitoring of marketing trends (Kropp. et al., 2008). In other words, proactiveness in entrepreneurship connotes firms acting in anticipation of future problems, needs, and/or change. At the embryonic stage of a firm's growth, proactiveness remains more critical in firm performance improvement (Coulthard, 2007; Hughes \& Morgan, 2007). Proactive firms are aware of and respond to market signals (Hughes \& Morgan, 2007). A proactive firm is opportunity seeking, forward-looking, and willing to introduce new products and services ahead of other competitors (Rauch.. et al., 2009). A firm with strong proactive tendencies tends to be able to anticipate changes in the the market and customer needs, forge a new market segment, and introduce new products and services ahead of competitors (Lumpkin \& Dess, 1996, 2001). Proactive firms seek new opportunities which may or may not be related to the present line of operations and introduce new products and brands ahead of competition, strategically eliminating operations in the declining stages of the life circle (Venkatraman, 1989). A proactive firm is expected to take the initiative and anticipate future problems, pursue new activities, introduce new products/services, and forge new markets. As a result, proactive firms become first movers and are rewarded with a marketplace position of competitive advantage with higher returns, distribution channels, and brand recognition. Previous studies have found a strong positive relationship between proactiveness and performance (Lumpkin \& Dess, 2001; Hughes \& Morgan, 2007; Rauch, Wiklund \& Frese, 2009).

\subsubsection{Innovativeness}

Rauch et al. (2009) describe innovativeness as the firm's ability and attempt to engage in new ideas or to innovate and create processes that may result in new products. Covin and Miles (1999) agree that without innovativeness, entrepreneurship cannot exist and that innovativeness is a crucial part of entrepreneurship survival strategies. However, in his investigation, Coulthard (2007) concluded that innovativeness is not the most important dimension for entrepreneurship survival. Landstrom (2005) opined that creativity is the source of innovativeness, which leads to innovation of products, services, processes, markets, and technology. Innovativeness tends to support novelty in the creation of new products and services. By increasing commitment to innovate products and processes, firms can improve their operations in the market and improve their profitability. Innovative companies generally have a broader base of skills and knowledge which gives them an edge over their competitors.

Miller and Friesen (1983) developed two models on innovation relative to a firm's goal and the type of organisation: the conservative and the entrepreneurial models. In the conservative model, a firm uses its innovative practice as a means of defence and retaliation against its competitors. This is done in an attempt to maintain or regain market 
position. The entrepreneurial model connotes a firm that consistently and aggressively pursues innovative practices internally which gives the organisation an edge over its competitors.

Innovation can be achieved through administrative innovativeness, which refers to an effective and efficient management backed up by modern information systems, control techniques, and organisational structure. It can also be achieved through technological innovation which is associated with research and development resulting in the development of new products and processes. Firms with innovative thoughts are able to improve existing product and develop new products or processes resulting in new market creation (Schumpeter, 1934). Innovation is an essential component of entrepreneurship and any other components of EO are a consequence of innovation (Covin \& Miller 1999). The importance of innovation as a contributing variable to the measurement of EO and performance is incontrovertible. A number of scholars have empirically verified the importance of innovation and the positive relationship between innovation and firm performance (Schumpeter, 1942; Covin \& Miles, 1999; Rauch et al., 2009; Coulthard, 2007).

The above confirms that a firm deploying EO is expected to develop skills to manage uncertainty, innovate to meet opportunities and threats, anticipate and predict the direction and nature of market change, tolerate risk, and offer autonomy to its staff. All these shape the firm's entrepreneurial capability to further improve business performance.

\section{External Environment and Firm Performance}

This section of the article examines the influence/impact of the external environment on an enterprise as well as its relationship with EO and firm performance.

It has been argued that the external environment impacts on the EO-firm performance relationship (Zahra 1996; Lumpkin \& Dess 2001; Wiklund \& Shepherd, 2005).

The external environment is defined as the "totality of physical and social factors that are taken directly into consideration in the decision-making behaviour of individuals or group in organisations" (Duncan, 1972). In other words, the external environment constitutes all elements and resources that exist outside the internal boundaries of a firm that have the potential to affect all and part of the firm (Daft, 1989). The influence of environmental variables on the EO-firm performance relationship has been researched by several scholars. They agree that the environment moderates the relationships between EO and firm performance (Lumpkin. \& Dess, 2001; Wiklund \& Shepherd, 2005; Zahra.. 1996). To further understand the effects of the external environment on the relationship between EO and firm performance this study discusses the following concepts.

\subsection{Environmental Munificence}

Environmental munificence (EM) refers to the availability of resources and the amount of external opportunities that are present in an environment (Zahra, 1993). In other word, EM is the scarcity or abundance of critical resources needed by (one or more) firms operating within an environment. This is directly related to a firm's ability to acquire resources from the market to actualise its dream. Studies have emphasised the importance of EM on the operations and performance of an entrepreneurial organisation as it enables organisations to pursue opportunities.

A munificent environment facilitates the proactiveness-performance relationship as the availability of resources enables firms to build strategic advantage (Miller \& Friesen, 1982). Lumpkin and Dess (2001) maintain that firms in environments with relatively scarce resources will abandon their proactive behaviours with the intent of managing the limited resources available. The authors elaborate that a munificent environment influences risk-taking in organisations, and that there is a positive relationship between risk and munificence as a result of environmental stability. The availability of opportunities offered to firms in a munificent environment makes it easier for them to attain their strategic initiatives. In such environment it is relatively easy for firms to acquire resources necessary to pursue organisational objectives, reduce the rate of threats from competitors, and increase growth rate.

\subsection{Environmental Dynamism}

Miller and Friesen (1983) posited that environmental dynamism (ED) is the rate of change and innovation in an industry as well as the uncertainty or the predictability of the actions of competitors and customers. ED consists of the velocity of environmental change, predictability, and unpredictability of the environment.

A dynamic environment relates to the level of unpredictable change in a firm's environment. Entrepreneurship scholars have emphasised the importance of a dynamic environment to the EO-performance relationship (Miller, 1983; Wiklund \& Shepherd, 2005). Miller (1983) suggested that firms operating in dynamic environments are more likely to participate in product innovation. Firms need to be proactive in a dynamic environment because it helps them to capitalise on market opportunities in a timely manner. Proactiveness enables organisations to do better and to 
capitalise on emerging opportunities leading to a competitive advantage (Lumpkin \& Dess, 1996; Zahra, 1993). Lumpkin and Dess (2001) found a positive relationship between proactiveness and dynamism which enhances a firm's performance.

The effect of environmental change on a firm can lead to a change in the behaviour of the firm in an industry. Covin, Slevin, and Heeley (2000) argue that a high rate of environmental dynamism creates numerous opportunities for firms to explore. Lumpkin and Dess (2001) confirmed that sales growth and profitability are positively and significantly related to proactive-dynamism. This means that a firm with a proactive orientation is positively associated with performance in a dynamic environment.

Empirical research suggests that a dynamic environment will moderate the relationship between organisational risk-taking and firm performance. Miller (1983) argues that firms that do not take risk in a dynamic environment will lose their share of the market to more aggressive competitors.

\subsection{Environmental Hostility}

A hostile environment negates both a dynamic and munificent environment. Miller and Friesen (1983) define environmental hostility as the degree of threat to a firm posed by the multifacetedness, vigour, and intensity of the competition and the up and down swings of the firm's principal industry. Environmental hostility (EH) is considered a threat to the viability of a firm, thereby reducing a firm's performance level. Many factors can be attributed to a hostile environment: the industry-specific variable, the location-specific variable, and rivalry among competitors.

Lumpkin and Dess (1996) argue that environmental characteristics may have a strong effect on the strength and direction of the relationship between EO and firm performance. Hostility indicates a scarcity of resources available in the environment as well as the level of competition for the available resources (Covin \& Slevin, 1989). Lumpkin and Dess (2001) refer to hostility as an obverse of munificence. Miller, Arnold, and Thompson (1993) studied 169 furniture manufacturers in a hostile environment and found that there is a significant negative correlation between hostility and entrepreneurial practice. A hostile environment is characterised by a greater level risk and uncertainty and has a negative impact on the organisation leading to adverse conditions. The negative impact of the environment on a firm can lead to strategic and managerial problems resulting in negative performance. However, firms with an innovative and proactive orientation and which are willing to take risk will benefit from hostile environments and improve their performance.

Lumpkin and Dess (2001) posit that hostile environmental conditions may force firms to abandon their proactive behaviours because of limited resources. This may hinder experimentation and discovery associated with proactiveness.

Firms that are entrepreneurially oriented are expected to maintain and possibly improve business performance under conditions of high environmental turbulence. This is because such firms are believed to possess the ability to react to constant shifts taking place in the environment through exploration and exploitation of new opportunities. Firms that lack EO risk strategic paralysis when faced with change. Such firms will be unable to profit from changing conditions and may lose their share of the market resulting in lower business performance.

In a complex situation of market turbulence, abilities derived from the embodiment of EO can assist the management of a firm to interpret the events resulting from market turbulence as an opportunity for further business model change, growth, and innovation as opposed to threats to undermine business.

\section{Entrepreneurship among Migrants}

From a global perspective, international migration has become a key feature of a modern society as found in most developed and developing countries. Migrants are persons who have been outside their country of birth for a period of 12 months or longer (Sasse \& Thielemann, 2005). The United Nation (2010) reported that there are an estimated 214 million international migrants worldwide. Out of this figure, 128 million of these reside in developed countries.

Migrant entrepreneurship refers to business activities undertaken by migrants from a specific socio-cultural and ethnic background or country of origin. This is different from normal entrepreneurship as its orientation is mostly towards migrant products, migrant market customers, or indigenous migrant business strategies. Masurel, Nijkamp, and Vindigni (2004) define ethnic migrant entrepreneurship as business activities in a certain area driven or undertaken by people of different ethnic or cultural origins than the dominant population. Daniels, Radebaugh, and Sullivan (2002) believe that immigration provides a good source of linkage among nations.

Immigrants have continued to be a feature of national life in most developed and developing countries. The personal networks of migrants have contributed greatly to the development of the economies in such countries, and has made 
them attractive to foreign investment and promoted trade with other countries. Migrants have further provided these countries with new sources of cultural knowledge, language skills, increased tourism, and stronger external links (Morgan, 2002). These migrants are found in all facets of business and economic activities. The increasing number of these migrants in urban and rural environments is likely to affect decisions regarding the employment/business opportunities that are available to them. A major element in immigrant social and economic integration in their host countries is tied to status attained through some form of employment.

Employment/business undertaken by migrants impacts their family viability, social acceptance, and personal esteem. However, in the absence of securing a job in the labour market, migrant entrepreneurial activities and self-employment are a promising springboard for immigrant social integration and reinforce immigrants' economic position and social status (Hunter, 2007; Masurel. et al., 2004).

Waldinger, Aldrich, and Ward (1990) argue that for migrant entrepreneurs to succeed requires personal attributes and market opportunities. The authors attribute the success of migrant groups to

- Pre-migration characteristics of the migrant. They note that migrants that have acquired the necessary business skills are more likely be successful in business.

- The circumstances of the migration. This has to do with what motivated the person to migrate. If he/she genuinely migrated for the purpose of setting up business and possesses the required skills, there a much stronger possibility that the business will succeed.

- Post migration characteristics such as the position of the migrant and how supportive the environment is to small businesses as well as migrant businesses.

However, migrant entrepreneurial decisions are influenced by individual, cultural, and societal factors. Migrants either aspire to be self-employed or are forced to be self-employed. Behaviours behind entrepreneurial choices are dynamic and complex; the decisional and behavioural patterns may be unique to different migrant groups. However, Metcalfe, Modood, and Virdee, (1996) believe that migrants opt for entrepreneurship for three basic reasons:

- The economic opportunity reason regard migrant business as relying on the market for success.

- The cultural reason assumes that for a migrant entrepreneur to attain his/her entrepreneurial goals, he/she needs cultural affiliation.

- The reactional reason assumes that self-employment among migrants is a reaction to their inability to secure a meaningful job. It is felt in most countries hosting migrants that migrants infuse their host countries with fresh ideas and new energy. Many countries agree that migrant entrepreneurs have helped in propelling the native economy (Chapple, Gorbey, \& Yeabsley, 1994). Migrants inject fresh capital, bring along new contacts and market knowledge, invest in new businesses, and create employment.

Daniels, Radebaugh, and Sullivan (2002) found that migrants have a positive impact on their host country's way of life, and migrant cultural influence has the greatest impact in cuisines and hospitality.

\section{Entrepreneurial Orientation and Small and Medium Enterprises}

Research confirms that there is some level of relationship between EO and SMEs. Wiklund (1999) asserts that EO strengthens the performances of small firms because smallness fosters the flexibility needed to make EO initiatives successful. This suggests that the smaller the size of a firm, the better the implementation of EO. According to Wiklund and Shepherd (2005), EO provides small businesses with the ability to discover new business opportunities and the discovery of new opportunities enhances their differentiation from other firms. Slater and Narver (1995) argue that EO helps small firms in product innovation and the control of new markets. Similarly, Zahra and Covin (1995) as well as Wiklund and Shepherd (2005) concluded that entrepreneurial orientation constitutes a key ingredient for enterprise success and leads to higher performance. Entrepreneurial orientation is also identified as a source of competitive advantage (Lumpkin \& Dess, 1996). Firms with a higher level of entrepreneurial orientation behaviour perform better than those with a lower level of entrepreneurial orientation behaviour (Lyon et al. 2000; Rauch et al. 2009).These research findings seem to suggest that entrepreneurial orientation enhances small and medium enterprise performance.

EO and SMEs are considered theoretically distinct but are necessary resources in the entrepreneurial literature (Stewart \& Roth, 2001). Stewart and Roth (2001) describe the entrepreneurial small business owner as "growth oriented", while Jenkin and Johnson (1997) define small business entrepreneurs as individuals who establish and manage a business for the purpose of furthering personal goals. Also, Carland, Carland, Hoy, and Boulton (1988) describe an entrepreneur as an individual who operates a small business for profit and growth. Carland, Hoy, and 
Carland (1984) differentiate the small business owner (SMO) from the entrepreneur in terms of the small business owner's extension of personality, the furtherance of personal goals, and the generation of family income. This position is corroborated by Jenkins and Johnson (1997) who point out that small business owners engage in coherent personal strategies such as making a living and having more leisure time. In fact, high EO among small business owners enhances the formation and activation of personal strategies that impact on business growth and performance. EO influences entrepreneurs and small business owners in their engagement in business and product innovation, and market development (Carland et al. 1984). From the above research findings, the line between entrepreneur and SMO is a thin one. However, it is evident that both SMOs entrepreneurs engage in business innovations. Therefore, it is assumed that, the amount of EO present affects the overall business success and performance of SMEs.

\section{Entrepreneurial Orientation and SME Performance}

The entrepreneurship literature has investigated the relationship between entrepreneurial orientation and firm performance (Wiklund \& Shepherd, 2005; Zahra \& Covin, 1995). Empirical evidence from Wiklund and Dess (2001) and Miller (1983) suggests that entrepreneurial orientation has positive influence on a firm's performance. Other research studies have found that entrepreneurial orientation leads to a higher market growth rate and firm performance (Wiklund \& Shepherd, 2003, 2005; Keh et al., 2007; Wang, 2008).

Wiklund and Shepherd's (2003) findings revealed that EO enhances the positive performance of firms. Wiklund and Shepherd (2005), in an investigation on the effect of the environment on EO and firm performance across 413 small firms in Sweden, found that EO positively influences the performance of small firms. In contrast, the environment exercises a controlling influence on the relationship between entrepreneurial orientation dimensions and SME performance. It has been emphasised that the EO-market information relationship plays a vital role in enhancing firm performance (Keh et al., 2007). Lumpkin and Dess (1996) posit that firms that are entrepreneurial oriented have the capabilities to discover and exploit market opportunities and can respond to challenges to prosper and flourish in the competitive and uncertain environment. These submissions indicate that EO enhances a firm's performance. Thus, entrepreneurial-oriented firms perform better than those that lack such orientation. In today's dynamic business environment, with the unpredictable nature of customers and the actions of competitors, firms need to regularly conduct innovation, take occasional and calculated risks, and aggressively compete to maintain position in the market as well as improve their performance.

However, there are opinions that have contradicted these views (Hughes \& Morgan, 2007). For instance, Hughes and Morgan found no correlation between EO dimensions and performance. There are contrary and mixed opinions on the relationship between EO and business performance (Hart, 1992; Tang \& Rothenberg, 2009). Entrepreneurship scholars have employed a variety of financial measures to ascertain the financial position of firms. Such measures include revenue, cash flow, returns on assets, returns on equity, and return on sales to measure a firm's performance. Aggarwal and Gupta (2006) argue that financial measures are necessary but not sufficient to capture the overall performance of firms. They suggest a combination of financial and non-financial measures to attain a more comprehensive evaluation of firm performance. Aggarwal and Gupta (2006) concluded that performance assessment also requires consideration of output and input perspectives. Output reflects a firm's key goal and profitability while input focuses on activities that are instrumental to the attainment of the end result.

On the other hand, Clark (1999) advocates for subjective non-financial measures such as perceived market share, perceived sales growth, customer satisfaction, loyalty, and brand equity. As shown in the discussion above researchers have suggested a range of approaches for measuring firm performance. However, the majority of opinions favour multiple measurements of firm performance. This is based on the argument that the entrepreneurial process can be favourable in one performance dimension but unfavourable in another dimension (Lumpkin \& Dess, 1996). To attain a broader and more comprehensive conceptualisation of firm performance multiple measures involving both financial and non-financial approaches should be adopted (Aggarwal \& Gupta, 2006; Murphy, Tranler, \& Hill, 1996). Murphy, Trailer, and Hills (1996), reviewed 51 published entrepreneurship studies. They found that most of the studies favoured efficiency, growth, and profit as their performance measures. As discussed earlier, there are five dimensions of EO. The relationship between EO and SME performance is briefly discussed below.

\subsection{Risk-taking}

Risk-taking orientation involves the willingness to invest resources in ventures or projects where the outcome may be highly uncertain or unknown (Wiklund \& Shepherd 2003). It is an investment of substantial funds in ventures with the intent of utilising environmental opportunities and realising higher returns (Lumpkin \& Dess, 1996). Justine, Anthony, and Max (2005) posit that risk-taking is a calculated action by a firm. They found that the risk-taking 
dimension of EO influences firm performance. This is supported by Wang and Yen (2012) who showed that risk-taking positively influenced firm performance among SMEs in Taiwan.

\subsection{Competitive Aggressiveness}

Firms that are competitively aggressive spend more than their competitors in terms of marketing activities, product service, and quality improvement which increase profitability. Competitive aggressiveness relates to a firm's ability to challenge competitors with the hope of improving its position in the market and increasing its earnings (Lumpkin \& Dess, 1996). Justin, Anthony, and Max (2005) found a positive relationship between competitive aggressiveness and firm performance. Their report suggested that price competitiveness is key to firm success. Based on the above empirical evidence, it can be concluded that competitive firms are more successful in the market.

\subsection{Autonomy}

Autonomy involves making quick, self-reliant decisions and required actions which enhance firm performance. It also includes internalisation activities and learning of autonomous operations.

Most firms with autonomous orientation maintain a stronger edge over their competitors (Miller, 1983; Lumpkin \& Dess, 1996) and it has been tested and confirmed that autonomous orientation is more pronounced among micro-entrepreneurs and small businesses (Lumpkin.. et al., 2009). Autonomy is attained when the structure and culture of the firm support decentralised decision making, free flow of information, socialisation, and flexible rules and regulations (Ireland, Covin, \& Kuratko, 2009; Lumpkin \& Dess, 1996).

Anthony and Max (2005) found autonomy to have a positive impact on the performance of the automotive component industry in Australia. Generally, opinions and empirical evidence from research have concluded that autonomy enhances the positive performance of firms.

\subsection{Proactiveness}

A firm's proactiveness means acting in advance and responding to unexpected or unanticipated occurrences. This involves timely responses through planning and decision-making processes in regards to operational issues which can improve a firm's operational status. A proactive firm anticipates and acts for future needs (Lumpkin \& Dess, 2001). Previous studies have found a strong positive relationship between proactiveness and SME performance (Hughes \& Morgan, 2007; Sascha, Coen, Marthew, \& Vincent, 2012; Wang \& Yen, 2012). For instance, Hughes and Morgan (2007) investigated selected firms in Vietnam and established that proactiveness influences the firms' performance. Studies by (Sascha et al., 2012) in Holland equally reported the important influence of innovativeness on firm performance. Wang and Yen (2012) emphasised that proactiveness is positively related to firm performance. Based on the aggregate reports from these studies, it is believed that proactiveness strongly influences firm performance.

\subsection{Innovativeness}

Innovation is a firm's ability to engage in new ideas or to innovate and create processes that may result in new products. Innovativeness is the propensity to support and engage in new ideas, experimentation, research, and development. Innovative firms usually seek to improve existing products and develop new products or processes resulting in new market creation. Innovation is an essential tool for the environmental exploitation of business opportunities. Hughes and Morgan (2007) reported a positive relationship between innovativeness and positive firm performance. In other meta-analyses it was found that the innovative behaviour of a firm significantly improves business performance over time (Justine... et al., 2005; Rauch.. et al., 2009; Zahra.. \& Bogner, 2000). (Rauch.. et al., 2009) suggest that for a firm to make headway among its peers in the industry, it must be innovative in all spheres of its existence.

\section{Environmental Influence}

Environmental characteristics constitute all resources (physical and social) existing outside the boundaries of an organisation with the potential to influence the decision-making behaviour of individuals or groups in an organisation. Covin.. et al. (2000); (Wiklund... \& Shepherd, 2005) acknowledge the influence of the environment on the strategic management of firms. It has also been shown that the environment moderates the relationship between EO and firm performance (Zahra, 1996; Lumpkin \& Dess, 2001; Wiklund \& Shepherd, 2005).

The risk-taking posture of an organisation is positively related to munificence as a result of environmental stability (Lumpkin \& Dess, 2001). Wiklund. and Shepherd (2003) reported that munificence moderates the EO-firm performance relationship. 
Equally, Lumpkin and Dess (2001) reported a positive relationship between proactiveness and a dynamic environment which enhances firm performance. According to Covin... and Slevin (1989), small firms perform best in a hostile environment. However, hostility is negatively related to entrepreneurial practice (Miller 1993). Hostility is indicative of the scarcity of resources available in the environment as well as the level of competition for the available resources (Covin \& Slevin, 1989). From the above empirical research findings, it can be concluded that environmental variables influence firm performance as a moderating variable and moderate the relationship between EO and SME performance.

\section{Conclusion}

The importance of migrants and migrant businesses cannot be overemphasised. Research has confirmed that immigrant entrepreneurs contribute immensely to the economic growth and development of both developing and developed countries of the world, as well as to social and cultural changes in these countries. Research has concluded that migrant entrepreneurial activity and self-employment are a springboard for social integration as they further reinforce the migrants' economic position and social status (Hunter, 2007; Masurel. et al., 2004).

This study is ongoing and it is assumed that as it progresses it will reveal how businesses devise entrepreneurial strategic approaches vital to their organisational successes. The study will also be able to analyse how EO can be used as a possible antidote to the problems facing businesses in their attempts to sustain a competitive environment. At the conclusion of the study it will be possible to determine if businesses that are innovative, proactive, competitively aggressive, take risks, and show autonomy are better off in business performance subject to the controlling influence of the environment. Wang and Runyan et al. (2008) found EO is important for business performance, with both a direct and indirect influence on firm performance (Keh et al., 2007).

The major limitation of this study will be the small number of participants proposed as a result of the financial constraint and time limit faced by the researcher. However, findings will still allow for the interpretation of the study, along with generalisations and recommendations however, generalisation may be limited because of small number of participants. Nevertheless, I suggest other studies use larger samples to investigate motivations to start a business and the challenges of running a business.

\section{References}

Acedo, F., Flori, J. (2006) An entrepreneurial cognition perspective on internationalization of SMEs. Journal of international Entrepreneurship, 4, 49-67. http://dx.doi.org/10.1007/s10843-006-0482-9

Aggarwal, N., \& Gupta, M. (2006). Marketing performance measures : current status in Indian companies. Decision, $33(1), 47-74$.

Al-swidi, A, K., \& Al-Hosam, A. (2012). The effect of Entreoreneurial Orientation on Organisational Performance: A study on Islamic Banks in Yemen using the partial least square approach. Arabian Journal of business and management review (OMAN Chapter) 2(1). http://dx.doi.org/10.12816/0002244

Avlonitis, G. J., \& Salavou, H. E. (2007). Entrepreneurial Orientation of SMEs, product innovativeness, and performance. Journal of business Reseach, 60, 566-575. http://dx.doi.org/10.1016/j.jbusres.2007.01.001

Babin, Z., \& Griffin, C. (2003). Business Research Methods: Macmillan Publishing.

Baird, I. S., \& Thomas, H. (1985). Toward a contingency model of strategic risk taking. Academy of Management Review, 10, 230-243.

Bollen, K. A. (1989). structural equation with latanet variables. New York: Wiley.

Bryman, A., \& Bell, E. (2007). Business Research Methods. New York: Oxford University Press.

Cantillon, R. (1734). Essay on the nature of general commerce. London, UK: Macmillan.

Carland, J. W., Carland, J. C., F, Hoy, F., \& Boulton, W. R. (1988). Distinctions between entrepreneurial and small business ventures. International Journal of Managemen, 5(1), 98-103.

Carland, J. W., Hoy, F., \& Carland, J. C. (1984). Differentiating entrepreneurs from small business owners: A conceptualization. Academy management review, 9(2).

Chapple, S., Gorbey, S., \& Yeabsley, J. (1994). Impact of immigration, Wellington New Zealand Institute of Economic Research .

Charney, A., \& Libercap, G. D. (2000). Impact of Entrepreneurship Education: Kauffman Centre for Entrepreneurial Leadership. 
Chin, W. W. (2010). Handbook of partial least squares: Concepts, Methods and Applications. Berlin: Springer.

Chin, W. W., \& Newsted, P. R. (1999). Structural equation modeling analysis with small samples using partial least squares. Thousand Oaks: Sage.

Clark, B. H. (1999). Marketing performance mearsures: History and interrelationships. Journal of marketing management, 15, 711-732. http://dx.doi.org/10.1362/026725799784772594

Coulthard, M. (2007). The role of entrepreneurial Orientation on firm performance and the potential influence of relational dynamism. Journal of global business and technology, 3, 29-39.

Covin, J. G., Slevin, D. P., \& Heeley. (2000). Pioneers and follower: Competitive tactics, environment and firm growth. Journal of business venturing, 15, 173-210.

Covin, J., \& Miles, M. (1999). Corporate entrepreneurship and the pursuit of competitive advantage. . Entrepreneurship: Theory \& Practice, 23(3), 47-63.

Covin, J., \& Slevin, D. P. (1989). Strategic management of small firms in hostile and benign environments. Strategic Management, 10, 75-87. http://dx.doi.org/10.1002/smj.4250100107

Cromie, S. (2000). Assessing entrepreneurial inclinations: Some approaches and empirical evidence. . European Journal of Work and Organisational Psychology, 9(1), 7-20. http://dx.doi.org/10.1080/135943200398030

Daft, R. (1989). Organisational theory and design: St Paul MN: West Publishing.

Daniel, J. D., Radebaugh, L. H., \& Sullivan, D. P. (2002). Globalization and business. New Jessey: Prentice Hall.

Dess, G. G., \& Beard, D. W. (1984). Dimensions of organisational task environments. Administrative science quartely, 29, 52-73. http://dx.doi.org/10.2307/2393080

Donaldson, L. (1996). Structural contigency theory. In Hand book of organisational studies, ed. Clegg, S., Hardy, C., \& Nord, W. London: Sage publications.

Duncan, R. B. (1972). Characteristic of organisational environments and perceived environmental uncertainties. Administrative science quartely, 17, 313-327. http://dx.doi.org/10.2307/2392145

Gartner. (1985). A conceptual framework for describing the phenomenon of new venture creation. Academy of Management Review, 10(4), 696-706.

Glancey, K., Greig, M., \& Pettigrew, M. (1998). Entrepreneurial dynamics in small business service firms. International journal of entrepreneurial behaviour \& Research, 4(3), 249-268. http://dx.doi.org/10.1108/13552559810235547

Hart, S. L. (1992). An integrated framework for strategy-making process. Academy of Management Review, 17, 327-351.

Hisrich, R. D., \& Peters, M. P. (2002a). Entrepreneurship. New York: McGraw-Hill/Irwin.

Hisrich, R. D., \& Peters, M. P. (2002b). Entrepreneurship. New York, NY: McGraw-Hill/Irwin.

Hughes, M., \& Morgan, R. E. (Eds.). (2007). Deconstructing the relationship between entrepreneurial orientation and business performance in the embryonic stage of firm growth (Vol. 36)

Hunter, I. (2007). Age of enterprise: rediscovering the New Zealand entrepreneur.1880-1910. Auckland: Auckland university press.

Hurley, R. F., \& Hult, G. T. M. (1998). Innovation, market orientation, and organisational learning: An integration and empirical examination. Journal of Marketing, 62, 42-54. http://dx.doi.org/10.2307/1251742

Indarti, N., \& Langenberg, M. (2005). A study of factors affecting business success among SMEs empirical evidence from Indonesia.

Ireland, R. D., Covin, J. G., \& Kuratko, D. F. (2009). Conceptualizing corporate entrepreneurship strategy. Entrepreneurial theory and practice, 33(1), 19-46. http://dx.doi.org/10.1111/j.1540-6520.2008.00279.x

Jenkins, M., \& Johnson, G. (1997). Entrepreneurial intensions and outcomes: A comparative causal mapping study. Journal of management studies, 34(6), 895-920. http://dx.doi.org/10.1111/1467-6486.00077

Justine, A., Anthony, L., \& Max, C. (2005). The impact of entrepreneurial orientation on the Australian Automotive Component Industry. Monash University, Department of management working paper series. 
Kloosterman, R., Van der Leun, \& Rath, J (1999). Mixed embeddedness: in formal economic activities and immigrant business in the Netherlands. international journalof urban and regional research, 23(2), 252-266. http://dx.doi.org/10.1111/1468-2427.00194

Kolveried, L. (1996). Prediction of Employment Status Choice Intensions. Entrepreneurial theory and practice, Fall, 47-57.

Kor, Y., Mahoney, J., \& Michael, S. (2007). Resources, Capabilities and Entrepreneurial Perceptions. Journal of Management Studies, 44(7), 1187- 1212. http://dx.doi.org/10.1111/j.1467-6486.2007.00727.x

Kristiansen, S., Furuholt, B., \& Wahid, F. (2003). Internet cafe entrepreneurs: pioneers in information dissemination in Indonesia. The International Journal of Entrepreneurship and Innovation, 4(4), 251-263. http://dx.doi.org/10.5367/000000003129574315

Kristiansen, S., \& Indarti, N. (2004). Entrepreneurial Intension among Indonesian and Norwegian Students. Journal of Enterprising Culture, 12(1). http://dx.doi.org/10.1142/S021849580400004X

Kropp, F., Linday, N. J., \& Shoham, A. (2008). Entrepreneurial Orientation and international entrepreneurial business venture startup. International journal of entrepreneurial behaviour \& Research, 14, 102-117. http://dx.doi.org/10.1108/13552550810863080

Landstrom, H. (2005). A History of Entrepreneurship and Small Business Research. In Landstrom, H. (Ed) Pionners in Entrepreneurship and Small Business Research. Springer Science+Business Medial Inc. http://dx.doi.org/10.1007/b102095

Lee, S. M., \& Peterson, S. J. (2000). Culture, Entrepreneurial Orientation,and Global competitiveness. Journal of World Business., 35, 401-416. http://dx.doi.org/10.1016/S1090-9516(00)00045-6

Levesque, M., \& Shepherd, D. A. (2004). Entrepreneurs' choice of entry strategy in emerging and developed markets. Journal of Business Venturing, 19(1), 29-54. http://dx.doi.org/10.1016/S0883-9026(02)00111-8

Lumpkin, G. T., Corgliser, C. C., \& Schneider, D. R. (2009). Understaging and measuring Autonomy: An entrepreneurial orientation perspective. Entrepreneurship Theory and practice. January(47-69). http://dx.doi.org/10.1111/j.1540-6520.2008.00280.x

Lumpkin, G. T., \& Dess, G. G. (2001). Linking two dimensions of entrepreneurial orientation to firm performance. Journal of Business Venturing, 16, 429-451. http://dx.doi.org/10.1016/S0883-9026(00)00048-3

Lumpkin, G. T., \& Dess, G. G. (1996). Clarifying the entrepreneurial orientation construct and linking it to performance. The academy of Management Review, 21, 135-172.

Lyon, D. W., Dess, G. G., \& Lumpkin, G. T. (2000). Enhancing entrepreneurial orientation research: Operationalizing and measuring a key strategic decision making process. Journal of Management Studies, 26(5), 1055. http://dx.doi.org/10.1177/014920630002600503

Masurel, E., Nijkamp, P., \& Vindigni. (2004). Breeding places for ethnic entrepreneurs. Entrepreneurship and Regional Developmen., 16(1), 77-86. http://dx.doi.org/10.1080/0898562042000205045

Mazzarol, T., Volery, T., Doss, N., \& Thein, V. (1999). Factors influencing small businessstart-ups. International journal of entrepreneurial behaviour \& Research, 5(2), 48-63. http://dx.doi.org/10.1108/13552559910274499

McMillan, I., C. (1982). Seizing competitive initiative. Journal of business strategy, 2, 43-57. http://dx.doi.org/10.1108/eb038944

Meyer, G. D., \& Heppard, K. A. (2000). Entrepreneurship as strategy.: CA: Sage Publications.

Miles, M. P., Arnold, D. R., \& Thompson, D. L. (1993). The interrelationship between environmental hostility and entrepreneurial orientation. Journal of Applied Business Research, 9(4), 12-23.

Miller, D. (1987). Strategy making and structure; Analysis and implications for performance. Academy of Management Journal, 30(1), 7-32. http://dx.doi.org/10.2307/255893

Miller, \& Friesen, P. (1983). Strategy-making and environment: The third link. Strategic Management Journal, 4 , 221-235. http://dx.doi.org/10.1002/smj.4250040304

Miller, D., \& Friesen, P. (1982). Innovation in conservative and entrepreneurial firms: Two models of strategic momentum. Strategic management journal, 3(1), 1-25. http://dx.doi.org/10.1002/smj.4250030102 
Mintzberg, H. (1973). Strategy making in three modes. California management review, 16(2), 44-53. http://dx.doi.org/10.2307/41164491

Mitchell, R. K., Smith, J. B., Morse, E. A., Seawright, K. W., Paredo, A. M., \& McKenzie, B. (2002). Are entrepreneurial cognitions universal? Assessing entrepreneurial cognitions across cultures. Entrepreneurship Theory \& Practice, 26, 9-32.

Monaughan, S. E. (2000). Capturing the entrepreneurial spirit: A study to identify the personality characteristics of entrepreneurs, not published. California School of Professional Psychology.

Morgan, G. (2002). Departing Kiwi fuel immigration dilemma. The National Business Review, 22.

Morris, M. H., Kuratko, D. F., \& Covin, J. D. (2008). Corporate entrepreneurship and innovation. Mason. Thomson Higher Education.

Morris, M. H. (2002). "Revisiting "who" is the entrepreneur. Journal of Developmental Entrepreneurship, 7(1), 5-7.

Mueller, S. I., \& Thomas, A. S. (2001). Culture and entrepreneurial potential: A nine country study of locus of countrol and innovativeness. Journal of business venturing, 16(1), 51-75. http://dx.doi.org/10.1016/S0883-9026(99)00039-7

Murphy, G. B., Tranler, J. W., \& Hill, R. C. (1996). Measuring performance in entrepreneurship research. Journal of business research, 36, 15-36. http://dx.doi.org/10.1016/0148-2963(95)00159-X

Nachmias, C. F., \& Nachmias, D. (1997). Research Methods in the Social Sciences. London: Arnold.

Patton, M. Q. (1990). Qualitative Evaluation and Research Methods (2nd ed.). Newbury Park, CA: Sage Publications, Inc.

Portter, M. E., \& Miller, V. E. (1985). How information gives you competitive advantage. Harvard business review, $37(1), 65-82$.

Rauch, A., Wiklund J, Lumpkin G, \& M, F. (2009). Entrepreneurial orientation and business performance: an assessment of past research and suggestion for the future. Entrepreneurship Theory \& Practice, 33(3), 761-787. http://dx.doi.org/10.1111/j.1540-6520.2009.00308.x

Renolds, P.D., Hay, M., Bygrave, W.D., Camp, M., \& Antonio, E. (2000). Global entrepreneurship Monitor 2000 Executive Report: Babson College, Kauffman Center for Entrepreneurial Leadership, and London Business School.

Sascha, K. J. P., Coen, R., Marthew, H., \& Vincent, H. (2012). Entrepreneurial orientation and business performance oof SMEs: a quantitative study from the Netherlands. Review of management science, 6(2), 161-182. http://dx.doi.org/10.1007/s11846-011-0062-9

Sasse, G., \& Thielemann, E. (2005). A research agenda for the study of migrants and minorities in Europe. Journal of Common Market Studies, 43, 655-671. http://dx.doi.org/10.1111/j.1468-5965.2005.00590.x

Schumpeter, J. A. (1934). The theory of economic development. Cambridge, MA.: Harvard University Press.

Sekaram, U. (2003). Research Methods for Business A Skill Building Approach: John Wiley \& Sons, Inc.

Slater, S. F., \& Narver, J. (1995). Market orientation and the learning organization. Journal of marketing, 59(3), 63-74. http://dx.doi.org/10.2307/1252120

Stewart, W. H., \& Roth, P. L. (2001). Risk propensity differences between entrepreneurs and managers: a meta-analysis review. Journal of Applied Psychology, 86(1), 145-153. http://dx.doi.org/10.1037/0021-9010.86.1.145

Tang, Z., \& Rothenberg, S. (2009). Does perceptual acuity matter? - An investigation of entrepreneurial orientation, perceptual acuity, and firm performance. Journal of Enterprising Culture, 17(1), 79-102. http://dx.doi.org/10.1142/S0218495809000278

Veal, A. J. (2005). Business Research Methods A Managerial Approach. Australia: Pearson Addison Wesley.

Venkatraman, N. (1989). Strategic orientation of business enterprises: The construct, dimensionality, and measurement. Management Science, 35, 942-962. http://dx.doi.org/10.1287/mnsc.35.8.942

Waldinger, R., H. , Aldrich, R., \& Ward, a. a. (1990). Ethnic Entrepreneurs: Immigrant Business in Industrial Societies. Newbury Park: CA: Sage. 
Wang, H. K., \& Yen, Y. F. (2012). An empirical exploration of corporate entrepreneurial orientation and performance in Taiwanese SMEs: A perspective of multidimensional construct. Total Quality Management and Business Excellence, 23(9-10), 1035-1044. http://dx.doi.org/10.1080/14783363.2012.670917

Wang, C.L. (2008). Entrepreneurial orientation, learning orientation, and firm performance. Journal of Entrepreneurship, 32(4), 635-657. http://dx.doi.org/10.1111/j.1540-6520.2008.00246.x

Wiklund, J., \& Shepherd, D. (2005). Entrepreneurial orientation, and small business performance; a configuration approach. Journal of Business Venturing, 20(1), 71-93. http://dx.doi.org/10.1016/j.jbusvent.2004.01.001

Wiklund, J., \& Shepherd, D. (2003). Knowledge-based resources, entrepreneurial orientation, and the performance of small and medium sized business. Strategic Management Journal, 24(13), 1307-1314. http://dx.doi.org/10.1002/smj.360

Wiklund, J. (1999). The sustainability of the entrepreneurial orientation-performance relationship. Entrepreneurship Theory \& Practice, 24(1), 37-48.

Williams, C. C., Round, J., \& Rodgers, P. (2010). Explaining the off-the-book enterprise culture of Ukraine: Reluctant or willing entrepreneurship? International journal of entrepreneurship small business, 10(2), 165-180. http://dx.doi.org/10.1504/IJESB.2010.033107

Yeabsley, J. (1997). Settling policy issues in migrant choice of settlement. Wellington, New Zealand:. New Zealand Institute of Economic Research.

Zahra, S. A., Sapienza, H. J., \& Davidson, P. (2006). Entrepreneurship and dynamic capabilities: A review model, and research agenda. Journal of Management Studies, 43(4), 917-955. http://dx.doi.org/10.1111/j.1467-6486.2006.00616.x

Zahra, S. A., \& Garvis, D. M. (2000). Entrepreneurship and firm performance: The moderating effect of international environmental hostility. Journal of business venturing, 15(5), 469-492. http://dx.doi.org/10.1016/S0883-9026(99)00036-1

Zahra, S. A., \& Bogner, J. G. (2000). Technology strategy and software new ventures' performance: Exploring the moderating effect of the competitive environment. Journal of Business Venturing, 15, 135-173. http://dx.doi.org/10.1016/S0883-9026(98)00009-3

Zahra, S. A. (1996). Governance, ownership and corporate entrepreneurship: The moderating impact of industry Technology opportunities. Academy management journal, 39(6), 1713-1735. http://dx.doi.org/10.2307/257076

Zahra, S. A., \& Covin, J. G. (1995). Contextual influences on the corporate entrepreneurship-performance relationship: A longitudinal analysis. Journal of Business Venturing, 10, 43-58. http://dx.doi.org/10.1016/0883-9026(94)00004-E

Zahra. (1993). Environment corporate entrepreneurship and financial performance: Ataxonomic approach. Journal of business venturing, 8, 319-340. http://dx.doi.org/10.1016/0883-9026(93)90003-N 